\title{
Ocena kreatywności uczniów \\ - wyzwanie dla systemu edukacji
}

DOI: 10.47050/65591876.134-158

Jan Fazlagić

Wyzwania pojawiające się na rynku pracy i w społeczeństwie w XXI w. wymagają czegoś więcej niż tylko poszerzania u uczniów umiejętności językowych i matematycznych. Na czoło wysuwa się szczególnie rozwijanie kreatywności jako tej kompetencji, którą będzie bardzo trudno zastąpić sztuczną inteligencją. Rozwój kreatywności u uczniów powinien służyć praktycznym celom związanym z przygotowywaniem ludzi do rozwiązywania nietypowych problemów, radzenia sobie z wieloznacznością, odpowiedzialnego podejmowania ryzyka. Dla zapewnienia przejrzystości i odpowiedzialności systemu edukacji od lat stosuje się w szkołach egzaminy i inne formy walidacji postępów w nauczaniu. Te obowiązujące aktualnie podejścia nie sprzyjają rozwijaniu kreatywności u uczniów - kreatywność jest cechą ucznia niedostrzeganą, „ślepą” dla systemu edukacji. Nowy system nauczania powinien znacznie więcej uwagi niż obecnie poświęcić rozwojowi sposobów i technik oceny kreatywności, aby uczniowie otrzymywali rzetelną informację zwrotną na temat swoich umiejętności w tym obszarze. Aby tak się stało, powinniśmy rozwijać i wdrażać nowe metody egzaminowania uczniów nastawione na ocenę ich kreatywności.

\section{Słowa kluczowe:}

kreatywność

system edukacji

egzaminy

uczenie się pod test 


\section{Assessment of students' creativity - a challenge for education systems}

DOI: 10.47050/65591876.134-158

Jan Fazlagić

The educational challenges for the $21^{\text {st }}$ Century go beyond the need for the development of communication skills and STEM programmes. In specific, creativity looms as a competence which is crucial due to the fact that it is very difficult to substitute it with Artificial Intelligence. The development of students' creativity should prepare them for solving practical; non-standard and ambiguous problems, responsible risk-taking and similar ill-defined, fuzzy problems. In order to ensure transparency and accountability examinations, other forms of validation of learning outcomes have to be implemented in schools. The current approaches to examinations do not support the development of creativity among students - creativity as a personal trait of a student is overlooked and the system of education is literally "blind" to it. A new system of education fit for the requirements of the $21^{\text {st }}$ century should provide students with hands-on and reliable feedback on their creativity skills. In order to achieve that goal new methods of examining should be implemented and adopted.

\section{Keywords:}

creativity

system of education

examinations

teaching-to-the-test 


\section{Wprowadzenie}

Systemy edukacji na świecie są teraz powszechnie krytykowane z powodu zbytniego przywiązania do egzaminów lub niemal ich "kultu" (OECD 2013; Fazlagić 2018b). Powszechna w latach 90. XX w. chęć sparametryzowania, „opomiarowania” wszystkich aspektów naszego życia, w szczególności funkcjonowania sektora publicznego, sprawiła, że do głównego nurtu (mainstreaming) polityk edukacyjnych wprowadzono na szeroką skalę egzaminy zewnętrzne. Obecnie systemy oświaty, nie tylko w Polsce, ale także w wielu innych krajach świata, stoją przed wieloma nowymi wyzwaniami. Oprócz problemu zmian klimatycznych akcentuje się brak dostatecznego nacisku na rozwój kompetencji proinnowacyjnych (OECD 2018). Emanacją tej sytuacji jest zjawisko "uczenia się pod test". W efekcie uczniowie nie rozwijają się $\mathrm{w}$ dostatecznym stopniu pod względem intelektualnym i emocjonalnym w zakresie m.in. krytycznego myślenia, wykorzystywania wyobraźni, zdolności do oceny etycznej własnych czynów, wytrwałości czy wreszcie kreatywności. W dalszej części niniejszego rozdziału zostanie przedstawiona pogłębiona analiza tego zjawiska oraz zostaną zaproponowane pewne rozwiązania i postulaty. Głównym celem niniejszego opracowania jest:

$\rightarrow$ Zwrócenie uwagi na to, że odpowiednio zaprojektowany system edukacji, przy uwzględnieniu jego wielkości (w warunkach polskich: kilkaset tysięcy nauczycieli, kilka milionów uczniów, tysiące szkół i placówek oświatowych itd.), może i powinien promować rozwój kreatywności u uczniów, m.in. poprzez zmodyfikowanie metod oceniania wyników nauczania.

$\rightarrow$ Zaproponowanie rozwiązań, które mogą zainspirować i wskazać kierunki zmian w podejściu do oceny postępów w nauce.

\section{Argumenty przemawiające za potrzebą zmiany akcentów w systemie oświaty}

Tradycyjna szkoła, która wyłoniła się na początku XIX w., powstała u progu ery industrialnej i miała służyć wdrożeniu niepiśmiennych obywateli w szybko rozwijających się społeczeństwach zachodnich do służby w wojsku i rozwijającym się przemyśle, a także w aparacie urzędniczym. Wówczas pruski model szkoły doskonale spełniał swoje zadanie transformacji społeczeństwa agrarnego w społeczeństwo industrialne. 
Obecnie, w XXI w., model ten jest jednak uznawany za hamulec na drodze do transformacji społeczeństwa industrialnego w społeczeństwo postindustrialne, szczególnie w krajach próbujących zniwelować lukę cywilizacyjną wobec Zachodu, takich jak np. Polska (Fazlagić 2015).

Zmiany w otoczeniu społeczno-gospodarczym sprawiają, że podstawowa cecha psychospołeczna człowieka, jaką jest inteligencja (mierzona m.in. za pomocą testów IQ), może utracić swoją dominującą rolę jako wyznacznik "przewagi konkurencyjnej” jednostki na rynku pracy. W XXI w. nadrzędną rolę w ocenie kompetencji, a także "selekcji pozytywnej" w systemie edukacji powinna odgrywać nie inteligencja ucznia (jak jest teraz, w szczególności jeden z jej elementów, tzn. dobra pamięć), lecz jego kreatywność. Wbrew pozorom taka reorientacja wcale nie musi pociągać za sobą rewolucyjnych zmian.

W literaturze można znaleźć wiele czynników warunkujących, zdaniem licznych badaczy, kreatywność człowieka, poziom inteligencji jest tylko jednym z nich (Nęcka 2012; Szmidt 2013). Wynika to z faktu, że kreatywność i inteligencja są ze sobą silnie skorelowane, lecz tylko do pewnego poziomu wartości współczynnika inteligencji IQ - poziom ten jest łączony w psychologii z tzw. hipotezą progu (threshold hypothesis). Zgodnie z nią w populacji osób o współczynniku IQ powyżej 120 będzie można zidentyfikować zarówno osoby o przeciętnie wysokiej (aczkolwiek nie niskiej) kreatywności, jak i wybitnie kreatywne jednostki. Wyzwaniem dla systemu edukacji jest więc zadbanie nie tyle o uczniów mniej inteligentnych (czyli dostrzeżenie ich, dowartościowanie, zapewnienie im wsparcia), co o tych, u których współczynnik inteligencji plasuje się powyżej progu $(I Q=120)$ i którzy nie są wybitnie uzdolnieni, jeśli chodzi o perspektywę inteligencji ogólnej. Tacy uczniowie dla wielu nauczycieli kierujących się klasycznymi kryteriami oceny „zdolności" ucznia będą "przeciętni”, ale nie wybitni. To właśnie ta grupa uczniów jest najbardziej niedoceniana w systemie edukacji, jeśli chodzi o wyniki, które uzyskuje w nauczaniu, vs. jej niewykorzystany/ nieoceniany potencjał intelektualno-emocjonalny. Wizerunek osoby wybitnie inteligentnej budzi pozytywne konotacje, które są wzmacniane przez proces edukacji w szkole. Jedną ze zmian, jakie można by wprowadzić w systemie edukacji w XXI w., mogłaby więc być afirmacja uczniów („bohaterów") kreatywnych w życiu szkolnym jako modeli-roli dla społeczności szkolnej (Kim 2005; Preckel i in. 2006; Silvia 2008; Karwowski, Gralewski, 2013; Benedyk i in. 2014). 
Rozwój gospodarczy w XXI w. w większym stopniu niż w poprzednich okresach będzie opierał się na wiedzy, innowacjach i przemysłach kreatywnych. Mimo dużego znaczenia bazy przemysłowej w XXI w. producenci produktów materialnych, takich jak samochody, samoloty, komputery, meble, dużo częściej niż w przeszłości będą korzystać z "miękkich" elementów uzyskiwania przewagi konkurencyjnej - utalentowanych pracowników, wzornictwa przemysłowego i innowacji marketingowych. Ponadto rozwój sztucznej inteligencji sprawi, że zapotrzebowanie na umiejętności wyższego rzędu, do których odnoszą się kompetencje przekrojowe, będzie rosło. W związku z tym w najbliższych latach większego znaczenia nabiorą kompetencje personalne i społeczne. Wynika to $z$ jednej strony ze zmian w stylu życia i środowiska, w jakim wychowuje się obecnie młodzież (mniej okazji do doskonalenia kompetencji personalnych i społecznych niż w przeszłości), a z drugiej ze zmian na rynku pracy. Kompetencje miękkie i interpersonalne są tym obszarem kształcenia, na którego deficyty pracodawcy w Polsce i na świecie wskazują najsilniej (Word Bank Group 2019). Wraz z postulatami wysuwanymi wobec systemu oświaty odnośnie do podniesienia jakości kształcenia kompetencji personalnych i społecznych pojawia się potrzeba opracowania metod ich obiektywnej oceny. Skuteczny system egzaminowania sprawdzający poziom kreatywności i kreatywnego potencjału ucznia powinien nie tylko pełnić funkcję sygnalizującą pracodawcom zdolności, umiejętności i możliwości absolwentów (na podstawie wyników egzaminów), lecz także dawać samym uczniom wskazówkę co do tego, jakie są oczekiwania pracodawców i w konsekwencji - jak je spełnić.

Według Raportu OECD (2016) stoimy przed nową rewolucją przemysłową, której materializacją będą m.in. druk 3D (produkcja przyrostowa, internet rzeczy i wykorzystanie robotów). W przemyśle stosowane będą nowe materiały m.in. (z użyciem nanotechnologii) oraz nowe procesy produkcji. Nowe technologie będą miały wpływ na produkcję i dystrybucję towarów i usług. Przemysł 4.0 (Industry 4.0) to zbiorcze pojęcie oznaczające integrację inteligentnych maszyn, systemów oraz wprowadzanie zmian w procesach produkcyjnych mających w celu zwiększanie wydajności wytwarzania oraz wprowadzenie możliwości elastycznych zmian asortymentu. Przemysł 4.0 dotyczy nie tylko technologii, ale też nowych sposobów pracy i nowych funkcji 
pełnionych przez pracowników w przemyśle (Piątek 2017). Będzie rosło znaczenie umiejętności interdyscyplinarnych (OECD 2016).

Analitycy brytyjskiego pisma „The Guardian" zidentyfikowali pięć kluczowych, rewolucyjnych zmian, jakie zajdą na rynku pracy w przyszłości (Five ways... 2017). Pierwszą z nich będzie stopniowe zanikanie sztywnych struktur organizacyjnych - w XXI w. przedsiębiorstwa nie będą ich potrzebowały. Według niektórych badań w ciągu ostatniego ćwierćwiecza przedsiębiorstwa na świecie "spłaszczyły się" o ok. $25 \%$. Zniknęło kilka warstw struktury organizacyjnej. W ich miejsce powstały struktury sieciowe. $Z$ tego też powodu zmienia się kształt ścieżek kariery. Ścieżka kariery przyszłości będzie miała kształt zygzakowaty. Drugim ważnym czynnikiem, który wpłynie na zmiany na rynku pracy, jest rozwój sztucznej inteligencji. W samych Stanach Zjednoczonych szacuje się, że $45 \%$ wszystkich stanowisk pracy będzie w latach 2015-2035 zagrożonych przez możliwość ich automatyzacji (Five ways... 2017). W tym samym okresie może zniknąć nawet $75 \mathrm{mln}$ miejsc pracy na całym świecie. Roboty i inteligentne systemy komputerowe mogą mieć większy wpływ na nasze życie, niż było w przypadku pojawienia się internetu. Informatyzacja będzie przyspieszała dzięki postępom w uczeniu się maszynowym (machine learning) oraz dzięki wzrostowi liczby danych, jakie gromadzimy wokół nas. Powstają już roboty, które potrafią wykonywać proste prace ręczne, np. pakowanie i przenoszenie towaru. Magazyny przyszłości będą pozbawione oświetlenia, ponieważ będą obsługiwane wyłącznie przez roboty.

W raporcie Światowego Forum Ekonomicznego czytamy, że do 2020 r. zniknie 5 mln miejsc pracy z powodu wprowadzenia do procesów produkcyjnych sztucznej inteligencji, robotów, nanotechnologii itp. $Z$ drugiej strony dokładnie $z$ tego samego powodu powstanie 2,1 mln nowych miejsc pracy (World Economic Forum 2016). Większość nowych miejsc pracy będzie wymagała zaawansowanych umiejętności. Klaus Schwab, założyciel i przewodniczący Światowego Forum Ekonomicznego (World Economic Forum 2016), jest przekonany, że rządy powinny podejmować działania zmierzające do przygotowywania pracowników do zmieniających się realiów. Profesor David Deming z Uniwersytetu Harvarda uważa, że najważniejsze będą umiejętności miękkie, takie jak współuczestniczenie w sieciach społecznych i negocjowanie. Jego zdaniem w nowoczesnych miejscach pracy pracownicy 
będą musieli odgrywać różne role - będzie to nieco przypominało funkcjonowanie dzieci w przedszkolu (wiele różnych ról, niska stabilność struktur społecznych, duże znaczenie empatii i współpracy). Deming zaproponował typologię różnych zawodów ze względu na dwie zmienne. Na osi X oznaczył umiejętności matematyczne, a na osi Y umiejętności społeczne. Na schemacie 1 przedstawiono przykłady zawodów ze względu na intensywność wykorzystywania umiejętności matematycznych i społecznych. Zawody w lewej dolnej ćwiartce nie wymagają ani zaawansowanych umiejętności społecznych, ani matematycznych. Z kolei zawody oznaczone w górnej prawej ćwiartce wymagają zarówno umiejętności społecznych, jak i matematycznych.

Schemat 1. Popyt na kompetencje matematyczne i społeczne wg zawodów

\begin{tabular}{c|c}
$\begin{array}{c}\text { prawnicy i sędziowie } \\
\text { policjanci } \\
\text { dentyści }\end{array}$ & $\begin{array}{c}\text { dyrektorzy finansowi } \\
\text { ekonomiści } \\
\text { lekarze }\end{array}$ \\
\hline $\begin{array}{c}\text { kierowcy ciężarówek } \\
\text { mechanicy samochodowi } \\
\text { spawacze }\end{array}$ & matematycy \\
& kasjerzy bankowi \\
& księgowi \\
& operatorzy maszyn
\end{tabular}

Źródło: The Future of Jobs... 2016.

\section{Rozwój kreatywności a system egzaminów}

Miernikiem zakończonego sukcesem procesu edukacji jest trwała zdolność posiadacza zdobytej wiedzy, rozwiniętych postaw i umiejętności do zastosowania ich w specyficznej sytuacji lub kontekście odnoszącym się bezpośrednio do definicji zawodu. Zakończony powodzeniem egzamin, który miałby stymulować (już przez samo swoje istnienie) rozwój kreatywności w szkole, powinien opierać się na innych założeniach niż egzamin sprawdzający wiedzę ucznia. Niektóre kompetencje mają charakter związany z wykazaniem się kreatywnością dziedzinową (domain-specific), a inne są uniwersalne, włączając $w$ to banalny już test na znalezienie jak największej liczby zastosowań spinacza (który nota bene został wynaleziony przez Polaka Józefa Hoffmana).

Odnosząc kwestię kreatywności ucznia do pojęcia umiejętności (a więc i potrzeb rynku pracy), można kreatywność zakwalifikować jako 
kompetencję przekrojową (transversal competence lub key competence) (Zimmermann 2018). Warto zauważyć, że kompetencje stanowią szerszy zakres pojęciowy niż wiedza i umiejętności (Rychen, Salganik 2000). Kompetencje mogą być definiowane jako „ogół wiedzy, umiejętności i postaw" (sum of knowledge, skills and attitudes - definicja stosowana przez Komisję Europejską). Z kolei OECD posługuje się bardziej rozbudowaną definicją uwzględniającą różne rodzaje kompetencji, z których na szczególne wyróżnienie w kontekście polskiego system edukacji zasługują:

$\rightarrow$ interaktywne wykorzystanie wiedzy i informacji,

$\rightarrow$ współpraca w heterogenicznych zespołach, w tym zarządzanie konfliktami i ich rozwiązywanie,

$\rightarrow$ autonomiczne działanie - rozumienie szerszego kontekstu, tworzenie planów na przyszłość i projektów związanych z życiem osobistym.

Umiejętności wiążą się z pewnym potencjałem do wykonywania zadań, a nie tym, co dana osoba wie. Kompetencje mogą charakteryzować zarówno jednostkę, jak i zespół, a także organizację. Kompetencje są pojęciem szerszym od umiejętności, ponieważ te drugie nie uwzględniają aspektów emocjonalnych (w tym związanych z motywacją do wykonywania zadań), a także systemu wartości, stosowanych strategii rozwiązywania problemów itp. W ramach kompetencji mieszczą się także nawyki i inne cechy psychologiczne jednostki (Guilland 2017). W dokumentach Komisji Europejskiej (The European Framework 2006) mowa jest o umiejętnościach poznawczych, takich jak komunikowanie się w języku ojczystym, komunikowanie się w językach obcych, kompetencje matematyczne, techniczne i z zakresu nauk ścisłych.

\section{Ocena a pomiar kreatywności ucznia}

Ocena (assessment) w edukacji jest definiowana jako proces zdobywania dowodów, dokonywania osądów i wyciągania wniosków dotyczących osiągnięć ucznia i jego dokonań (Curtis 2010). Ocena wiąże się więc z fazą analizy i zbierania danych oraz fazą wnioskowania i wartościowania. Najrzetelniejszą metodą pomiaru kompetencji są testy psychometryczne. Wykorzystywane są one powszechnie w procesie rekrutacji, ale także przy budowaniu zespołów, wspieraniu rozwoju zawodowego 
oraz w procesie zarządzania zmianą. Popularność testów, w tym realizowanych za pomocą internetu, stale rośnie ze względu na ich niski koszt i przeprowadzanie, obiektywność i porównywalność wyników oraz możliwość szybkiego przeprowadzenia na dużej populacji pracowników lub kandydatów. Testy te służą zbadaniu nie wszystkich kompetencji, jakimi dysponuje kandydat/pracownik, lecz przede wszystkim tych, które są potrzebne pracodawcy.

Ocena kompetencji jest szczególnie trudna, ponieważ trudno je precyzyjnie zdefiniować. Wiąże się z następującymi wyzwaniami (Gibb 2014):

$\rightarrow$ ustalenie kontekstu, czyli wkładu ze strony podmiotu dokonującego oceny - chodzi o właściwe zdefiniowanie wzorca doskonałości, który byłby punktem odniesienia do pomiaru;

$\rightarrow$ ustalenie treść zadań egzaminacyjnych;

$\rightarrow$ ustalenie metody weryfikacji, w szczególności poziomu zaangażowania osoby egzaminowanej - można wykorzystywać testy wiedzy, ale także symulacje i obserwację uczestniczącą; odpowiedzi deklarowane nie zawsze będą tożsame z rzeczywistymi zachowaniami danej osoby;

$\rightarrow$ wykorzystanie wyników oceny - wyniki oceny powinny pomagać osobom ocenianym $w$ dalszym podnoszeniu swoich umiejętności; osoby oceniane powinny być samoświadome swoich zachowań, a wyniki powinny ułatwiać im znajdowanie motywacji wewnętrznej (być pozytywnymi bodźcami).

Reasumując, ocena kompetencji transferowalnych powinna (Ketchagias 2011):

$\rightarrow$ służyć celom diagnostycznym, ocenie formatywnej i sumatywnej, certyfikacji;

$\rightarrow$ wykorzystywać modele rozwoju kompetencji oparte na odkryciach z dziedziny kognitywistyki i dostosowywać do tych odkryć testy psychometryczne;

$\rightarrow$ wykorzystywać nowe media;

$\rightarrow$ wprowadzać ocenę umiejętności pracy w grupie i współpracy;

$\rightarrow$ uwzględniać kompetencje obywatelskie (local and global citizenship);

$\rightarrow$ umożliwiać sprawdzanie umiejętności uczniów dostosowane do indywidualnych cech ucznia. 
Ocena nie powinna odgrywać wyłącznie roli certyfikującej i podsumowującej proces nauczania. Powinna także być źródłem edukacji i motywatorem do dalszej nauki i doskonalenia się (Wiggins 1998). W związku z tym wszelkie nowoczesne formy egzaminowania stosowane w oświacie powinny uwzględniać postulat edukacyjno-rozwojowy. Zadania egzaminacyjne powinny być tak zaprojektowane i sformułowane, aby dawać uczniom wskazówki co do dalszego rozwoju. Właściwie zaprojektowane zadania egzaminacyjne powinny dostarczać informacji zwrotnej na temat aktualnego poziomu umiejętności ucznia oraz informować, jak powinien się rozwijać. Bardzo ważne jest także kształcenie takich umiejętności, które będą mogły być wykorzystywane przez ucznia w zróżnicowanych kontekstach (transferability of knowledge and competences) (Packer, Goicoechea 2000).

Tabela. 1. Kompetencje i sposoby ich oceny

\begin{tabular}{|c|c|c|c|}
\hline LP. & $\begin{array}{l}\text { NAZWA } \\
\text { I OPIS } \\
\text { KOMPE- } \\
\text { TENCJI }\end{array}$ & $\begin{array}{l}\text { POŻĄDANE ZACHOWANIE } \\
\text { PRACOWNIKA W MIEJSCU PRACY } \\
\text { WYNIKAJĄCE Z POSIADANIA DANEJ } \\
\text { KOMPETENCJI }\end{array}$ & $\begin{array}{l}\text { MOŻLIWE SPOSOBY WERYFIKACJI/OCENY W FORMIE } \\
\text { ZADANIA EGZAMINACYJNEGO }\end{array}$ \\
\hline 1. & $\begin{array}{l}\text { Dostrze- } \\
\text { ganie } \\
\text { emocji }\end{array}$ & $\begin{array}{l}\text { Pracownik dostrzega emocje } \\
\text { członków zespołu, przełożo- } \\
\text { nego, klientów i innych osób } \\
\text { i potrafi je nazwać. }\end{array}$ & $\begin{array}{l}\text { 1. Krótki film (Digital roleplay) pokazujący } \\
\text { sytuację w miejscu pracy, np. kłótnię między } \\
\text { pracownikiem a klientem, której świadka- } \\
\text { mi są inni klienci i przełożony. Uczeń ma } \\
\text { za zadanie opisać emocje uczestników } \\
\text { scenki. Poszczególni bohaterowie mogą się } \\
\text { różnie zachowywać (film powinien zostać } \\
\text { nakręcony przez zawodowych aktorów; dla } \\
\text { utrudnienia film powinien powstać w kilku } \\
\text { wariantach, tak aby w każdym wariancie } \\
\text { daną postać charakteryzowały inne emocje, } \\
\text { np. klient może być w jednym wariancie } \\
\text { przestraszony, a w drugim zdziwiony, z kolei } \\
\text { przełożony pracownika w jednym wariancie } \\
\text { może stać po stronie klienta, a w drugim być } \\
\text { zły na klienta itd.). Zadaniem osoby egzami- } \\
\text { nowanej jest nazwanie emocji poszczegól- } \\
\text { nych uczestników scenki. }\end{array}$ \\
\hline
\end{tabular}




\begin{tabular}{|c|c|c|c|}
\hline 2. & $\begin{array}{l}\text { Używanie } \\
\text { emocji }\end{array}$ & $\begin{array}{l}\text { Pracownik potrafi adekwat- } \\
\text { nie zareagować na zdarzenie } \\
\text { w swoim otoczeniu, używając } \\
\text { w odpowiedni sposób swoich } \\
\text { emocji. }\end{array}$ & $\begin{array}{l}\text { Testowanie tego typu kompetencji jest } \\
\text { utrudnione, ponieważ należałoby naj- } \\
\text { pierw wywołać pewne naturalne emocje, } \\
\text { np. przestraszyć, stworzyć zagrożenie, } \\
\text { obrazić osobę egzaminowaną. Z przyczyn } \\
\text { etycznych testowanie takich zachowań } \\
\text { jest niemożliwe lub bardzo utrudnione } \\
\text { (wszelkie formy „łagodniejszej" ekspozycji } \\
\text { na emocje w trakcie symulacji mogą nie dać } \\
\text { rzetelnych wyników). } \\
\text { Można natomiast przedstawić opisy sytu- } \\
\text { acji (w formie pisemnej lub, jak opisano to } \\
\text { wyżej - w formie filmu) i prosić osobę eg- } \\
\text { zaminowaną o ocenę zasadności zachowań } \\
\text { ocenianej postaci. W ten sposób można, } \\
\text { przynajmniej na poziome deklaratywnym, } \\
\text { ocenić, czy osoba egzaminowana zna wła- } \\
\text { ściwe sposoby używania emocji w różnych } \\
\text { sytuacjach. } \\
\text { W filmie osoba egzaminowana ma dokony- } \\
\text { wać oceny sytuacji (Situational Judgement } \\
\text { Test). Film co kilkanaście sekund jest prze- } \\
\text { rywany, a osoba uczestnicząca w egzaminie } \\
\text { (uczeń) ma za zadanie odpowiedzieć na } \\
\text { pytanie o wielu wariantach odpowiedzi. }\end{array}$ \\
\hline 3. & $\begin{array}{l}\text { Rozumie- } \\
\text { nie emocji }\end{array}$ & $\begin{array}{l}\text { Pracownik jest świadomy swo- } \\
\text { ich emocji, potrafi je nazwać } \\
\text { i zna ich konsekwencje dla swo- } \\
\text { jego funkcjonowania i relacji } \\
\text { z innymi. }\end{array}$ & $\begin{array}{l}\text { Rozumienie emocji nie jest tożsame ze } \\
\text { zdolnością do ich werbalnego określenia. } \\
\text { Ważniejsza jest "szczerość z samym sobą" } \\
\text { tzn. m.in. zdolność do przyznania się do } \\
\text { błędu, przyznanie przed samym sobą, że } \\
\text { kogoś się uraziło lub zraniło (poczucie } \\
\text { winy). }\end{array}$ \\
\hline 4. & $\begin{array}{l}\text { Zarzą- } \\
\text { dzanie } \\
\text { emocjami }\end{array}$ & $\begin{array}{l}\text { Umiejętność opanowywania } \\
\text { stresu, powstrzymanie się od } \\
\text { agresywnych zachowań. }\end{array}$ & $\begin{array}{l}\text { Ta umiejętność może być sprawdzana } \\
\text { najskuteczniej w rzeczywistych sytuacjach } \\
\text { wymagających zarządzania emocjami: trud- } \\
\text { no stosować takie podejście sprawdzające } \\
\text { umiejętności osoby egzaminowanej w cza- } \\
\text { sie egzaminu szkolnego. Można natomiast } \\
\text { posłużyć się metodami egzaminowania } \\
\text { sprawdzającymi poziom świadomości zna- } \\
\text { czenia zarządzania emocjami. }\end{array}$ \\
\hline
\end{tabular}




\begin{tabular}{|c|c|c|c|}
\hline 5. & $\begin{array}{l}\text { Zarzą- } \\
\text { dzanie } \\
\text { relacjami } \\
\text { z innymi }\end{array}$ & $\begin{array}{l}\text { (Współ)tworzenie atmosfery } \\
\text { sprzyjającej produktywnej } \\
\text { pracy w zespole pracowni- } \\
\text { ków, podtrzymywanie relacji } \\
\text { zawodowych i osobistych ze } \\
\text { współpracownikami i klienta- } \\
\text { mi (tam, gdzie to wskazane), } \\
\text { dobieranie adekwatnych form } \\
\text { i treści w komunikacji interper- } \\
\text { sonalnej. }\end{array}$ & $\begin{array}{l}\text { Ta umiejętność może być sprawdzana } \\
\text { najskuteczniej w rzeczywistych sytuacjach } \\
\text { wymagających zarządzania relacjami z inny- } \\
\text { mi ludźmi: trudno stosować takie podejście } \\
\text { sprawdzające umiejętności osoby egzamino- } \\
\text { wanej w czasie egzaminu szkolnego. Można } \\
\text { natomiast posłużyć się metodami egzami- } \\
\text { nowania sprawdzającymi poziom świadomo- } \\
\text { ści znaczenia zarządzania relacjami. Można } \\
\text { ucznia pytać o to, jakimi kryteriami kieruje } \\
\text { się w nawiązywaniu znajomości, jakie ma } \\
\text { podejście do kultywowania znajomości. } \\
\text { W pewnych zawodach (przede wszystkim } \\
\text { usługowych) zarządzanie relacjami z innymi } \\
\text { może być kluczową kompetencją, np. } \\
\text { w hotelarstwie, handlu, sprzedaży, usługach } \\
\text { prawniczych itd. }\end{array}$ \\
\hline 6. & $\begin{array}{l}\text { Myślenie } \\
\text { strategicz- } \\
\text { ne }\end{array}$ & $\begin{array}{l}\text { Dotyczy zdolności do podej- } \\
\text { mowania decyzji, dokonywania } \\
\text { wyborów między różnymi } \\
\text { opcjami, rozumienia krótko- } \\
\text { i długookresowych konsekwen- } \\
\text { cji swoich działań. }\end{array}$ & $\begin{array}{l}\text { Sprawdzenie tej kompetencji wymaga stwo- } \\
\text { rzenia sytuacji, w której osoba egzaminowa- } \\
\text { na na podstawie będących w jej dyspozycji } \\
\text { informacji ma podjąć jakąś decyzję życiową } \\
\text { lub zawodową. Decyzja ta może dotyczyć } \\
\text { zaciągnięcia kredytu hipotecznego, zmiany } \\
\text { miejsca pracy, przeprowadzki do innego } \\
\text { miasta, zakupu dobra trwałego użytku itp. } \\
\text { Osoba egzaminowana w zadanym czasie } \\
\text { na podstawie będących w jej dyspozycji } \\
\text { informacji ma podjąć decyzję, a następie } \\
\text { ją uzasadnić. Ocena kompetencji może } \\
\text { odbyć się zarówno na podstawie odpowiedzi } \\
\text { na pytania wielokrotnego wyboru, jak i na } \\
\text { podstawie rozmowy oceniającej (ocena jako- } \\
\text { ściowa). Przy ocenie myślenia strategicznego } \\
\text { oprócz samej decyzji należy zweryfikować } \\
\text { schematy myślowe i sam proces myślenia } \\
\text { prowadzący do danej decyzji. } \\
\text { Zadanie może być utrudniane przez wpro- } \\
\text { wadzenie w czasie jego rozwiązywania } \\
\text { dystraktorów (czynników rozpraszających } \\
\text { uwagę, przeszkadzających w skupieniu). } \\
\text { W ten sposób można także oceniać zdolność } \\
\text { do radzenia sobie ze stresem i jego wpływ na } \\
\text { jakość podejmowanych decyzji. }\end{array}$ \\
\hline 7. & $\begin{array}{l}\text { Zarządza- } \\
\text { nie sobą } \\
\text { w czasie }\end{array}$ & $\begin{array}{l}\text { Dotyczy planowania swojej } \\
\text { pracy i odpoczynku, wyboru } \\
\text { priorytetów, delegowania zadań. }\end{array}$ & $\begin{array}{l}\text { Zadanie może polegać na wykorzystaniu } \\
\text { jednego z wielu narzędzi zarządzania sobą } \\
\text { w czasie. Osoba egzaminowana mogłaby } \\
\text { za pomocą jednego z takich narzędzi opra- } \\
\text { cować plan lub analizę swojego tygodnia } \\
\text { i zasugerować w drugiej części jego optyma- } \\
\text { lizację (plan poprawy). }\end{array}$ \\
\hline
\end{tabular}




\begin{tabular}{|c|c|c|c|}
\hline 8. & $\begin{array}{l}\text { Zdolność } \\
\text { do odnaj- } \\
\text { dywania } \\
\text { sensu } \\
\text { (sense- } \\
\text {-making }\end{array}$ & $\begin{array}{l}\text { W miarę jak robotyzacja i auto- } \\
\text { matyzacja coraz większej liczby } \\
\text { działań będą postępować, } \\
\text { umiejętności techniczne zwią- } \\
\text { zane z obsługą maszyn, w tym } \\
\text { także programowaniem, będą } \\
\text { stawać się zbędne. Komputery } \\
\text { dzięki swojej mocy obliczenio- } \\
\text { wej będą w stanie zastępować } \\
\text { człowieka w takich zadaniach } \\
\text { jak analiza danych. Najsłabszą } \\
\text { stroną komputerów jest ich } \\
\text { niezdolność do wykazywania } \\
\text { się inteligencją. W związku } \\
\text { z tym obszarami, w których } \\
\text { ludzie będą nadal dominować } \\
\text { nad maszynami, będzie zdol- } \\
\text { ność do krytycznego myślenia } \\
\text { i tworzenia sensu. Można więc } \\
\text { powiedzieć, że jeśli ktoś myśli } \\
\text { o swojej karierze w perspekty- } \\
\text { wie } 15-20 \text { lat, powinien raczej } \\
\text { inwestować swój czas w sa- } \\
\text { morozwój w obszarze filozofii, } \\
\text { etyki, socjologii, historii. }\end{array}$ & $\begin{array}{l}\text { Wszelkie zadania, w których problem jest } \\
\text { nieprecyzyjnie zdefiniowany (ill-defined). } \\
\text { Zadania z nieprecyzyjnie zdefiniowanym } \\
\text { problemem trudniej oceniać, ponieważ ist- } \\
\text { nieje wiele możliwych rozwiązań problemu. } \\
\text { Przy ich ocenie należy brać pod uwagę sam } \\
\text { proces dochodzenia do rozwiązania, a nie } \\
\text { tylko uzyskany wynik. Proces rozumowania } \\
\text { oparty na jak największej liczbie zmiennych } \\
\text { i hipotez sformułowanych przez osobę } \\
\text { egzaminowaną powinien być odpowiednio } \\
\text { wyżej oceniony niż proces oparty na małej } \\
\text { liczbie hipotez i zmiennych wziętych pod } \\
\text { uwagę. }\end{array}$ \\
\hline 9. & $\begin{array}{l}\text { Zdol- } \\
\text { ność do } \\
\text { adaptacji } \\
\text { i elastycz- } \\
\text { ność }\end{array}$ & $\begin{array}{l}\text { Ta kompetencja pojawia się już } \\
\text { w propozycjach zadań egza- } \\
\text { minacyjnych na } 2019 \text { r., lecz } \\
\text { występuje pod nieprecyzyjna } \\
\text { nazwą "zarządzanie zmianą". } \\
\text { Wiąże się z efektywnością } \\
\text { w rozwiązywaniu proble- } \\
\text { mów wymagających myśle- } \\
\text { nia krytycznego. Na rynku } \\
\text { pracy następuje polaryzacja } \\
\text { zapotrzebowania na kompe- } \\
\text { tencje pracowników. Zanikają } \\
\text { zawody wymagające średnich } \\
\text { umiejętności, ponieważ zostają } \\
\text { one wyparte przez automaty- } \\
\text { zację (np. bankowość) lub przez } \\
\text { offshoring. Jednocześnie rośnie } \\
\text { liczba miejsc pracy wymagają- } \\
\text { cych bardzo niskich kwalifikacji } \\
\text { oraz zawodów wymagających } \\
\text { bardzo wysokich kwalifikacji. } \\
\text { W tej drugiej grupie zawodów } \\
\text { szczególnie liczy się zdol- } \\
\text { ność do adaptacji do nowych } \\
\text { warunków. }\end{array}$ & $\begin{array}{l}\text { Zdolność do adaptacji i elastyczność są bar- } \\
\text { dzo często wymieniane jako pożądane cechy } \\
\text { pozytywne uczniów i absolwentów systemu } \\
\text { edukacji. Są one jednak silnie powiązane } \\
\text { z osobowością, na której konstrukcję ma } \\
\text { wpływ nie tylko wychowanie, ale też geny. } \\
\text { Podstawą zwiększania adaptacyjności jest } \\
\text { trening opuszczania strefy komfortu. Im } \\
\text { większa jest strefa komfortu danej osoby, } \\
\text { tym trudniej jest jej poddać się procesowi } \\
\text { zmiany. Zdolność do adaptacji i elastyczność } \\
\text { są związane z tolerancją ryzyka. Tolerancja } \\
\text { ryzyka jest według wielu badań cechą danej } \\
\text { kultury. Według powszechnie uznawa- } \\
\text { nych na świecie badań autorstwa Geerta } \\
\text { Hofstede polską kulturę narodową cechuje } \\
\text { bardzo wysoki wskaźnik unikania ryzyka } \\
\text { (uncertainty avoidance), który wynosi } 93 \text {. } \\
\text { Dla porównania dla Niemiec wynosi on } 65, \\
\text { dla Wielkiej Brytanii } 35, \text { dla Czech } 74, \text { dla } \\
\text { Stanów Zjednoczonych 46. Konkludując, } \\
\text { ocena adaptacyjności ucznia jest możliwa, } \\
\text { natomiast trudno jednoznacznie przypisy- } \\
\text { wać ją wpływowi systemu edukacji. Wpływ } \\
\text { czynników kulturowych i genetycznych jest } \\
\text { tutaj znaczący. }\end{array}$ \\
\hline
\end{tabular}




\begin{tabular}{|c|c|c|c|}
\hline 10. & $\begin{array}{l}\text { Kompe- } \\
\text { tencje } \\
\text { między- } \\
\text { kulturowe }\end{array}$ & $\begin{array}{l}\text { Rosnąca globalizacja powoduje, } \\
\text { że zarówno wśród pracowników, } \\
\text { jak i klientów coraz większej } \\
\text { liczby firm pojawiają się osoby } \\
\text { z innych krajów i kultur. Kiedyś } \\
\text { wiedza o innych kulturach } \\
\text { pochodziła z książek podróż- } \\
\text { niczych, filmów fabularnych } \\
\text { i dokumentalnych. Dzisiaj coraz } \\
\text { więcej sytuacji w naszym życiu } \\
\text { wiąże się z koniecznością inte- } \\
\text { rakcji z osobami z innych kultur. } \\
\text { Często oznacza to akceptację } \\
\text { dla odmiennych zachowań, } \\
\text { a także konieczność uczenia się } \\
\text { i adaptacji do nich. }\end{array}$ & $\begin{array}{l}\text { Kompetencje międzykulturowe nie powinny } \\
\text { być utożsamiane z akceptacją dla różno- } \\
\text { rodności (choć są z nią silnie powiązane). } \\
\text { Chodzi tutaj o zdolność do skutecznego } \\
\text { zarządzania zespołami wielokulturowymi } \\
\text { i pracy w nich zespołach. } \\
\text { Początek procesu weryfikacji tej kompetencji } \\
\text { powinien obejmować sprawdzenie wiedzy na } \\
\text { temat specyfiki różnych kultur (istnieje bogata } \\
\text { literatura na temat cech specyficznych różnych } \\
\text { kultur, także w kontekście kultury współpracy). } \\
\text { Na wyższym poziomie zweryfikowane powinny } \\
\text { zostać zdolności do pracy w zespołach wielo- } \\
\text { kulturowych. Można posłużyć się filmami in- } \\
\text { struktażowymi. Osoba egzaminowana powinna } \\
\text { zdefiniować specyficzne zachowania członków } \\
\text { zespołu i opisać ich przyczyny. }\end{array}$ \\
\hline 11. & $\begin{array}{l}\text { Kompe- } \\
\text { tencje } \\
\text { medialne }\end{array}$ & $\begin{array}{l}\text { Umiejętność korzystania z no- } \\
\text { wych mediów stanie się niedłu- } \\
\text { go bardzo ważna, ponieważ tra- } \\
\text { dycyjne media, takie jak radio } \\
\text { czy telewizja, będą traciły swój } \\
\text { monopol. Jeszcze } 10 \text { lat temu } \\
\text { w podręcznikach marketingu } \\
\text { internet był traktowany jako } \\
\text { medium pomocnicze na równi } \\
\text { z banerami, gadżetami itp. }\end{array}$ & $\begin{array}{l}\text { Osoba egzaminowana powinna odróżniać: } \\
\rightarrow \text { opinie od faktów; } \\
\rightarrow \text { plotki od informacji publiczne; } \\
\rightarrow \text { prezentację obiektywną od subiektywnej; } \\
\rightarrow \text { prezentację realistyczną od surrealistycz- } \\
\text { nej, dramatycznej, nadmiernie dramatycznej } \\
\text { i melodramatycznej; } \\
\rightarrow \text { reklamę od przekazu niekomercyjnego; } \\
\rightarrow \text { gatunki dziennikarskie (reportaż, film fabu- } \\
\text { larny, film komediowy, dramat, wiadomości); } \\
\rightarrow \text { problemy życia rzeczywistego od proble- } \\
\text { mów prezentowanych w mediach. } \\
\text { Ponadto uczeń powinien znać sposoby } \\
\text { manipulacji widzem, narzucania przez media } \\
\text { stereotypów. }\end{array}$ \\
\hline 12. & $\begin{array}{l}\text { Między- } \\
\text { dyscypli- } \\
\text { narność }\end{array}$ & $\begin{array}{l}\text { Wiele z dzisiejszych problemów, } \\
\text { jakie nas otaczają, nie może } \\
\text { być rozwiązana dzięki wiedzy } \\
\text { z jednej dyscypliny naukowej. Dla } \\
\text { pracowników firm zajmujących } \\
\text { się analizą trendów rynkowych } \\
\text { i pracowników centrów badaw- } \\
\text { czo-rozwojowych oznacza to, że } \\
\text { będą musieli poruszać się w po- } \\
\text { przek dyscyplin. Biolodzy będą } \\
\text { musieli zrozumieć matematykę, } \\
\text { a matematycy biologię. Idealny } \\
\text { pracownik przyszłości to ktoś, } \\
\text { kto jest wyposażony w umiejęt- } \\
\text { ności w kształcie litery „"T"1. }\end{array}$ & $\begin{array}{l}\text { Uczeń powinien wykazać się zdolnością do } \\
\text { myślenia dywergencyjnego, czyli zmiany } \\
\text { kierunku myślenia i perspektywy. Można } \\
\text { to zweryfikować na podstawie udzielanych } \\
\text { odpowiedzi w kontekście problemów wyma- } \\
\text { gających skomplikowanych rozwiązań. }\end{array}$ \\
\hline
\end{tabular}

Koncepcja kompetencji w kształcie litery $T$ (T-shaped skills) lub osób posiadających takie kompetencje (T-shaped persons) jest metaforą ilustrującą przecinanie się lub współwystępowanie kompetencji niepowiązanych ze sobą dziedzinowo, np. umiejętność pisania wierszy + umiejętność programowania robota. Umiejętności te są bardzo cenione na rynku pracy, ponieważ ułatwiają budowanie multidyscyplinarnych zespołów. 


\begin{tabular}{|c|c|c|c|}
\hline 13. & $\begin{array}{l}\text { Zdolność } \\
\text { do radze- } \\
\text { nia sobie } \\
\text { z przeła- } \\
\text { dowaniem } \\
\text { kognityw- } \\
\text { nym }\end{array}$ & $\begin{array}{l}\text { Dotyczy umiejętności filtrowania } \\
\text { i ignorowania pewnych infor- } \\
\text { macji. W sytuacji, gdy zalewa } \\
\text { nas rosnący strumień informa- } \\
\text { cji, zdolność do umiejętnego } \\
\text { selekcjonowania ma kluczowe } \\
\text { znaczenie dla produktywności } \\
\text { pracownika. }\end{array}$ & $\begin{array}{l}\text { Kompetencja ta jest związana w dużym } \\
\text { stopniu z ogólną zdolnością do koncentra- } \\
\text { cji oraz zarządzania sobą. Można ją badać } \\
\text { na podstawie zdolności do dokonywania } \\
\text { selekcji informacji. Uczeń mógłby w czasie } \\
\text { zadania egzaminacyjnego dokonać wyboru } \\
\text { wartościowych informacji spośród szerszego } \\
\text { zbioru informacji ważnych i nieważnych. }\end{array}$ \\
\hline 14. & $\begin{array}{l}\text { Zdolność } \\
\text { do projek- } \\
\text { towania } \\
\text { (design } \\
\text { mindset) }\end{array}$ & $\begin{array}{l}\text { Z wielu badań wynika, że } \\
\text { sposób, w jaki zaprojektujemy } \\
\text { nasze otoczenie, ma wpływ na } \\
\text { to, jak postrzegamy świat oraz } \\
\text { jak się zachowujemy (Eberhard, } \\
\text { Patoine 2004). }\end{array}$ & $\begin{array}{l}\text { Projektowanie jest typową kompetencją } \\
\text { przekrojową. Projektować można wszyst- } \\
\text { ko, bez względu na rodzaj wykonywanego } \\
\text { zawodu. Stąd też zadania egzaminacyjne } \\
\text { powinny być dostosowane do specyfiki } \\
\text { zawodu osoby egzaminowanej. }\end{array}$ \\
\hline 15. & $\begin{array}{l}\text { Ocena } \\
\text { i analiza } \\
\text { długoter- } \\
\text { minowych } \\
\text { konse- } \\
\text { kwencji } \\
\text { zjawisk } \\
\text { i działań }\end{array}$ & $\begin{array}{l}\text { Orientacja długookresowa jest } \\
\text { typową kompetencją prze- } \\
\text { krojową. Wiąże się z realizacją } \\
\text { celów długookresowych oraz } \\
\text { powstrzymaniem się od szybkiej } \\
\text { gratyfikacji. Przydaje się zarówno } \\
\text { przy zarządzaniu pracą własną, } \\
\text { jak i w pracy zespołowej. } \\
\text { Hamowanie jest jedną z naszych } \\
\text { najczęściej używanych funkcji } \\
\text { poznawczych. To sposób, wjaki } \\
\text { mózg koryguje zachowanie. Ha- } \\
\text { mowanie sprawia, że możliwe dla } \\
\text { nas staje się, aby siedzieć cicho, } \\
\text { gdy chcemy coś powiedzieć, ale } \\
\text { wiemy, że nie należy tego robić. } \\
\text { Pomaga też zachować spokój } \\
\text { i pozycję siedząca, kiedy jeste- } \\
\text { śmy w klasie, pomaga zachować } \\
\text { bezpieczeństwo i czujność, gdy } \\
\text { ktoś zmienia pas bez używania } \\
\text { kierunkowskazu, pomaga studio- } \\
\text { wać lub pracować nawet wtedy, } \\
\text { gdy znudzimy się lub chcemy } \\
\text { wstać (Czym jest hamowanie?). }\end{array}$ & $\begin{array}{l}\text { Nieskuteczne hamowanie może przejawiać } \\
\text { się na trzech różnych poziomach (Czym jest } \\
\text { hamowanie?): } \\
\rightarrow \text { motorycznym: jeśli brakuje umiejętności } \\
\text { kontroli zachowań motorycznych, objawia } \\
\text { się to nadpobudliwością; } \\
\rightarrow \text { uwagi: przejawia się roztargnieniem } \\
\text { i trudnościami w utrzymaniu uwagi, np., gdy } \\
\text { czytamy książkę i jesteśmy rozproszeni, po- } \\
\text { nieważ słyszymy dzwonek do drzwi sąsiada } \\
\text { lub widzimy cień gołębicy przechodzącej } \\
\text { po parapecie; } \\
\rightarrow \text { zachowań: przejawia się w nieprzemyśla- } \\
\text { nych postawach, przykładowo, naciska się } \\
\text { wściekle na klakson, gdy światło zmieniło } \\
\text { się na zielone, ale kierowca z przodu nie } \\
\text { ruszył automatycznie. } \\
\rightarrow \text { Kompetencję tę można badać w sytu- } \\
\text { acjach symulowanych, w których osoba } \\
\text { egzaminowana nie zna celu badania (jest on } \\
\text { ukryty). }\end{array}$ \\
\hline 16. & $\begin{array}{l}\text { Umiejęt- } \\
\text { ność pracy } \\
\text { zespoło- } \\
\text { wej }\end{array}$ & $\begin{array}{l}\text { Może objawiać się w wielu róż- } \\
\text { nych sytuacjach, wśród których } \\
\text { można wymienić np. pracę nad } \\
\text { kilkoma projektami jednocześnie } \\
\text { dla kilku zlecających, aktyw- } \\
\text { ność sportową, uczestnictwo } \\
\text { w stowarzyszeniach, harcerstwie, } \\
\text { zbiórkach publicznych na cele } \\
\text { charytatywne itd. Najważniejsze } \\
\text { jest wykazanie przed pracodaw- } \\
\text { cą swojej sprawności społecznej. }\end{array}$ & $\begin{array}{l}\text { Umiejętność tę można sprawdzać zarówno } \\
\text { dzięki analizie dotychczasowej aktywności } \\
\text { osoby egzaminowane, jak i w sytuacjach } \\
\text { symulowanych. Należy zwrócić uwagę, że } \\
\text { umiejętność pracy zespołowej wiąże się } \\
\text { w dużym stopniu z właściwym dobraniem } \\
\text { kompetencji członków zespołu do wykony- } \\
\text { wanego zadania. Nie można na podstawie } \\
\text { powierzchownej obserwacji i arbitralnej } \\
\text { oceny stwierdzić, że dana osoba jest lub nie } \\
\text { jest dobrym "graczem zespołowym". }\end{array}$ \\
\hline
\end{tabular}

Źródło: opracowanie własne. 
Szkoła stanowi doskonałe miejsce na rozwijanie kreatywności u uczniów, ponieważ oferuje możliwości stymulacji umysłu, z którymi uczeń nie mógłby zetknąć się w innych sytuacjach (np. w domu, na wakacjach z rodzicami, w czasie edukacji domowej). Nawet w swojej obecnej, archaicznej formie ma olbrzymi potencjał. Nie można przy tym lekceważyć ustaleń psychologii kreatywności, która podkreśla znaczenie przeszkód (constraints) jako stymulatora rozwoju kreatywności. Innymi słowy, to, co z perspektywy krótkoterminowej uznajemy za przeszkodę („zabijanie kreatywności”), może mieć w dłuższej perspektywie pozytywny wpływ na sukcesy absolwentów szkoły. Postać innowatora, niedocenianego przez otoczenie, który mimo przeszkód odnosi sukces, jest dość powszechna w świadomości zbiorowej. W popkulturze określa się ją czasami mianem underdog, czyli kogoś, komu nie daje się szans na wygraną. Tę skuteczność w przezwyciężaniu przeszkód można i należy powiązać ze wcześniejszą edukacją szkolną w tym znaczeniu, że "szkoła zabijająca kreatywność" to jednocześnie szkoła ucząca walki z przeszkodami na drodze do rozwoju kreatywności, niezrozumieniem ze strony otoczenia, wrogością, życiem w poczuciu bycia niedocenianym itd.

Nie można mówić o rozwoju kreatywności u uczniów bez wskazania na kluczową rolę samych nauczycieli. Z badań wynika, że kreatywność nauczycieli jest tutaj niezbędna (Meintjes, Grosser 2010). Kreatywny nauczyciel na potrzeby danej sytuacji w klasie konstruuje doświadczenia w czasie lekcji, często improwizując i modyfikując swoje, znane mu wcześniej strategie i pomysły. Kluczowa jest więc nie tyle "kreatywność" zawarta w zaplanowanym z góry scenariuszu czy podstawie programowej. To spontaniczne dostosowywanie zachowania nauczyciela do danej sytuacji decyduje o wartości kreatywnej edukacji. I na odwrót, najbardziej "kreatywny” scenariusz lekcji realizowany przez pozbawionego entuzjazmu nauczyciela ściśle trzymającego się schematu nie będzie dobrym sposobem na rozwój kreatywności uczniów (Hojat 2004). Susan Brookhart $(2010,2013)$ zaproponowała Rubrics of Creativity, czyli sposób ewaluacji kreatywności. Zgodnie z nim kreatywność można oceniać w dwóch wymiarach i według czterech stopni oceny, odpowiednio: bardzo kreatywny, kreatywny, zwykły/ rutynowy i imitacyjny. $W$ drugim wymiarze kreatywności znajdują się następujące kryteria oceny: różnorodność idei i kontekstów, różnorodność wykorzystywanych przez ucznia źródeł, używanie pomysłów 
z różnych źródeł - kombinacja, wniesienie nowej wartości/przedstawienie nowej jakości. Jednak zdaniem autorki jej koncepcja nie ma służyć klasycznej ocenie, lecz przede wszystkim pomagać nauczycielom w przybliżeniu kryteriów oceny kreatywności ucznia. Innymi cechami kreatywnego ucznia, które mogłyby być brane pod uwagę przy jego ocenie, są m.in.:

$\rightarrow$ zdolność do syntetyzowania pomysłów w oryginalny i zadziwiający sposób (kryterium zadziwienia odbiorców/publiczności jest uznawane za jeden z predyktorów kreatywności dzieła),

$\rightarrow$ zadawanie pytań, ogólna ciekawość poznawcza,

$\rightarrow$ szeroki zakres poszukiwań, otwarcie umysłu na inspiracje z różnych obszarów,

$\rightarrow$ zdolność do komunikowania/przedstawiania swojego pomysłu odbiorcom.

\section{Kreatywność ucznia jako wyzwanie dla systemu egzaminów i oceny pracy ucznia}

Niektórzy eksperci jako przyczynę niewystarczającego nacisku na kształtowanie kompetencji proinnowacyjnych w szkołach wskazują brak instrukcji i wskazówek dla nauczycieli we wszystkich krajach europejskich w kwestii sposobu nauczania kreatywności. W tabeli 2 przedstawiono przykłady zadań egzaminacyjnych (w odniesieniu do egzaminu zawodowego w zawodzie górnik eksploatacji podziemnej), które zostały opatrzone komentarzem dotyczącym możliwości ich modyfikacji w taki sposób, aby w czasie ich rozwiązania zwrócono większą uwagę na ocenę kreatywności ucznia. Komentarze te ilustrują tezę, że zwiększenie znaczenia pomiaru kreatywności w szkole niekoniecznie musi wiązać się ze zmianami rewolucyjnymi dla funkcjonowania szkoły. Bardzo często drobne modyfikacje czy przeniesienie akcentu mogą diametralnie przesunąć punkt ciężkości pomiaru w danym zadaniu - w kierunku postulowanego zwiększenia nacisku na ewaluację kreatywności ucznia. 


\section{Tabela 2. Ocena propozycji kształcenia}

\begin{tabular}{|c|c|}
\hline $\begin{array}{c}\text { ELEMENT PODSTAWY } \\
\text { PROGRAMOWEJ } \\
\text { (EFEKTY KSZTAECENIA ORAZ } \\
\text { KRYTERIA WERYFIKACJI) }\end{array}$ & $\begin{array}{l}\text { UWAGI I SUGESTIE ZWIĄZANE Z MOŻLIWOŚCIĄ UDOSKONALENIA POD } \\
\text { KĄTEM KOMPETENCJI PRZEKROJOWYCH }\end{array}$ \\
\hline \multicolumn{2}{|c|}{$\begin{array}{l}\text { PODSTAWA PROGRAMOWA KSZTAŁCENIA W ZAWODZIE GÓRNIK EKSPLOATACJI PODZIEMNEJ. } \\
\text { SYMBOL CYFROWY ZAWODU 811101. Poziom III Polskiej Ramy Kwalifikacji określony dla zawodu } \\
\text { jako kwalifikacji pełnej. KWALIFIKACJA WYODRĘBNIONA W ZAWODZIE: GIW.11. Eksploatacja } \\
\text { złóż podziemnych. Poziom } 3 \text { Polskiej Ramy Kwalifikacji określony dla kwalifikacji. }\end{array}$} \\
\hline
\end{tabular}

\begin{tabular}{l|l}
\hline 1. charakteryzuje pojęcia & Należy położyć nacisk nie tylko na identyfikowanie, ale także
\end{tabular} związane z bezpieczeństwem na społeczny kontekst zachowań, np. wpływ na otoczenie, śroi higieną pracy, ochroną $\quad$ dowisko naturalne, długookresowe negatywne skutki naruszenia przeciwpożarową, ochroną przepisów dla społeczeństwa oraz długookresowe pozytywne środowiska i ergonomią. $\quad$ skutki dbałości o ochronę środowiska.

2. charakteryzuje prawa i obowiązki pracownika oraz pracodawcy w zakresie bezpieczeństwa i higieny pracy.

3. określa skutki oddziaływania czynników środowiska pracy w górnictwie na organizm człowieka.

Potrafi w opisanej sytuacji wskazać, jakie prawa zostały naruszone lub jakie będą konsekwencje danego zachowania pracownika.

5. wykonuje zadania zawodowe zgodnie z zasadami bezpieczeństwa i higieny pracy, ochrony przeciwpożarowej, ochrony środowiska i ergonomii.

2. rozróżnia rodzaje znaków bezpieczeństwa i alarmów.

3. charakteryzuje prawa i obowiązki pracownika oraz pracodawcy w zakresie bezpieczeństwa i higieny pracy.

Ten obszar wiedzy można testować na podstawie przedstawienia osobie egzaminowanej scenariuszy. Zadanie polegałoby na wyborze właściwego/najbardziej odpowiedniego/korzystnego scenariusza.

Należy ściśle zdefiniować procesy wykonywane z zasadami i z ich naruszeniem. Warto dokonać gradacji procesów/zadań ze względu na ich niebezpieczeństwo (tzn. nie klasyfikować wykonanych zadań wyłącznie zerojedynkowo (naruszył zasady $\mathrm{BHP} /$ nie naruszył zasad BHP).

Warto by poszerzyć o sprawdzenie wiedzy o konsekwencjach nieprzestrzegania zaleceń zawartych w znakach itp.

Warto także zwrócić uwagę na relacje między pracownikami. Wiele naruszeń prawa w miejscach pracy dotyczy relacji międzypracowniczych (m.in. mobbing i bullying).

Potrafi w opisanej sytuacji wskazać, jakie prawa zostały naruszone lub jakie będą konsekwencje danego zachowania pracownika.

Tak jak w poprzednich przypadkach, zaleca się poszerzenie metod egzaminowania o ocenę identyfikacji sytuacji na przykładzie scenek sytuacyjnych (studiów przypadków). Osoba egzaminowana miałaby za zadanie odpowiedzieć na kilka pytań dotyczących opisanej (lub obserwowanej - można posłużyć się np. komiksem) sytuacji. Taki sposób egzaminowania byłby podobny do pytań egzaminacyjnych na prawo jazdy. Kandydat na kierowcę na podstawie zdjęcia z ruchu ulicznego ma wykazać się wiedzą 
GIW.11.8. Język

obcy zawodowy

1. uczeń posługuje się podstawowym zasobem środków językowych w języku obcym nowożytnym (ze szczególnym uwzględnieniem środków leksykalnych).
Należałoby stworzyć coś w rodzaju podstawy programowe języka zawodowego. Powinna ona zawierać listę np. 200 słów specjalistycznych.

Ponadto warto zastanowić się, czy rzeczywiście lepiej jest stawiać na język "zawodowy", czy też lepiej stworzyć zunifikowaną podstawę języka angielskiego dla szkół zawodowych, w ramach której istniałby komponent ściśle związany z danym zawodem (np. 200 słów, 200 zwrotów itp.).

Źródło: opracowanie własne.

\section{Propozycje zadań egzaminacyjnych możliwych do wykorzystania w ramach egzaminu potwierdzającego kwalifikacje w zawodzie, sprawdzających kompetencje przekrojowe}

Na podstawie ustaleń definicyjnych i analizy w tabeli 3 zaprezentowano kilka zadań egzaminacyjnych możliwych do wykorzystania w ramach egzaminu potwierdzającego kwalifikacje w zawodzie w taki sposób, aby położyć większy nacisk na ocenę kreatywności ucznia.

Tabela 3. Opis zadań egzaminacyjnych uwzględniających kompetencje przekrojowe

\begin{tabular}{|c|c|c|}
\hline $\begin{array}{l}\text { NAZWA ZADANIA } \\
\text { EGZAMINOWANE } \\
\text { KOMPETENCJE } \\
\text { PRZEKROJOWE }\end{array}$ & OPIS ZADANIA & KRYTERIA OCENY \\
\hline $\begin{array}{l}\text { 1. Bezpieczeń- } \\
\text { stwo i higiena } \\
\text { pracy, ochrona } \\
\text { przeciwpoża- } \\
\text { rowa, ochrona } \\
\text { środowiska } \\
\text { i ergonomia } \\
\text { Wiedza o struk- } \\
\text { turze organiza- } \\
\text { cyjnej państwa } \\
\text { w kontekście } \\
\text { społeczno-eko- } \\
\text { nomicznym } \\
\text { wykonywanego } \\
\text { zawodu }\end{array}$ & $\begin{array}{l}\text { Zadanie powinno opisywać sytuację } \\
\text { kryzysową w kontekście konkretne- } \\
\text { go zawodu (np. górnika). Powinno } \\
\text { sprawdzać także wiedzę o procedu- } \\
\text { rach reagowania w sytuacjach za- } \\
\text { grożenia zdrowia i życia, np. w czasie } \\
\text { symulowanych scenek z miejsca wy- } \\
\text { padku lub poprzez obserwacje filmu } \\
\text { instruktażowego (osoba egzamino- } \\
\text { wana powinna po jego obejrzeniu } \\
\text { wskazać na błędy popełnione przez } \\
\text { bohaterów filmu w ich zachowaniu). }\end{array}$ & $\begin{array}{l}\text { Liczba zidentyfikowanych błędów } \\
\text { popełnionych przez bohatera lub bo- } \\
\text { haterów filmu. Za wskazanie działania } \\
\text { jako błędnego, które w istocie jest } \\
\text { prawidłowe, powinny być przyznawane } \\
\text { punktu ujemne. } \\
\text { Osoba egzaminowana ponadto ma } \\
\text { wskazać, jaką rolę w usuwaniu skutków } \\
\text { sytuacji kryzysowej mogą odgrywać } \\
\text { przedstawiciele jego zawodu, jak mogą } \\
\text { się przydać ich kompetencje. }\end{array}$ \\
\hline
\end{tabular}




\begin{tabular}{|c|c|c|}
\hline $\begin{array}{l}\text { 2. Zarządza- } \\
\text { nie kryzysowe } \\
\text { Zadania } \\
\text { i uprawnienia } \\
\text { instytucji oraz } \\
\text { służb działajq- } \\
\text { cych w zakresie } \\
\text { ochrony pracy } \\
\text { i ochrony środo- } \\
\text { wiska w Polsce }\end{array}$ & $\begin{array}{l}\text { Sprawdzenie wiedzy w tym zakresie } \\
\text { odbywa się w formie analizy studium } \\
\text { przypadku konkretnej sytuacji } \\
\text { kryzysowej. Osoba egzaminowana } \\
\text { ma wskazać, jakie instytucje powinny } \\
\text { być zaangażowane w usuwanie } \\
\text { skutków, jakie powinny być relacje } \\
\text { między nimi w procesie zarządzania } \\
\text { kryzysowego itp. }\end{array}$ & $\begin{array}{l}\text { Osoba egzaminowana analizuje } \\
\text { opis sytuacji kryzysowej (np. klęska } \\
\text { powodzi). Jej zadaniem jest wskazanie } \\
\text { instytucji, które powinny brać udział } \\
\text { w usuwaniu skutków analizowa- } \\
\text { nej sytuacji. } \\
\text { Ponadto należy wskazać wynikające } \\
\text { z opisanej sytuacji skutki dla gospo- } \\
\text { darki i społeczeństwa. Dane zawarte } \\
\text { w opisie (np. powódź na terenach } \\
\text { turystycznych, w lipcu) powinny być } \\
\text { wskazówką dla odpowiedzi dotyczącej } \\
\text { ekonomicznych strat dla branży tury- } \\
\text { stycznej w regionie itp. }\end{array}$ \\
\hline $\begin{array}{l}\text { 3. Zagrożenia } \\
\text { związane z wy- } \\
\text { stępowaniem } \\
\text { czynników } \\
\text { w środowi- } \\
\text { sku pracy } \\
\text { Umiejętność } \\
\text { zachowania } \\
\text { bezpieczeń- } \\
\text { stwa własnego } \\
\text { oraz współ- } \\
\text { pracowników } \\
\text { i klientów }\end{array}$ & $\begin{array}{l}\text { Zadanie powinno angażować } \\
\text { osobę egzaminowaną. Powinna ona } \\
\text { w zainscenizowanej sytuacji podjąć } \\
\text { właściwe działania. } \\
\text { Osoba egzaminowana w czasie egza- } \\
\text { minu ogląda krótki (120-180 sekund) } \\
\text { film przedstawiający zachowanie } \\
\text { aktora w sytuacji związanej z wyko- } \\
\text { nywanym zawodem, z którego składa } \\
\text { egzamin. }\end{array}$ & $\begin{array}{l}\text { Zadaniem osoby egzaminowanej jest } \\
\text { odpowiednie zachowanie się w zain- } \\
\text { scenizowanej sytuacji, np. podczas } \\
\text { wypadku przy pracy. Egzaminator } \\
\text { powinien sprawdzić, czy podjęto wła- } \\
\text { ściwe działania, np. odłączono zasilanie } \\
\text { od urządzenia będącego na miejscu } \\
\text { zdarzenia, zawiadomiono w poprawny } \\
\text { sposób pogotowie, udzielono pierwszej } \\
\text { pomocy itp. zaniechanie działań } \\
\text { niezbędnych lub (np. nieodłączenie } \\
\text { prądu) powinno skutkować punktami } \\
\text { ujemnymi. }\end{array}$ \\
\hline $\begin{array}{l}\text { 4. Posługiwanie } \\
\text { się podstawo- } \\
\text { wym zaso- } \\
\text { bem środków } \\
\text { językowych } \\
\text { w języku obcym } \\
\text { nowożytnym } \\
\text { (ze szczegól- } \\
\text { nym uwzględ- } \\
\text { nieniem } \\
\text { środków } \\
\text { leksykalnych) }\end{array}$ & $\begin{array}{l}\text { Test językowy polegający na uzupeł- } \\
\text { nieniu pustych miejsc w zdaniach } \\
\text { o odpowiedni wyraz. Test ma } \\
\text { sprawdzać znajomość słownictwa } \\
\text { zawodowego. }\end{array}$ & $\begin{array}{l}\text { Osoba egzaminowana powinna uzu- } \\
\text { pełnić tekst o brakujące słowa. } \\
\text { Innymi, komplementarnymi formami } \\
\text { egzaminowania mogą być m.in.: } \\
\rightarrow \text { napisanie tekstu krótkiego maila } \\
\text { opisującego problem zawodowy; } \\
\rightarrow \text { odpowiedź na mail w języku angiel- } \\
\text { skim dotyczący problemu klienta; } \\
\rightarrow \text { opisanie zdjęcia przedstawiającego } \\
\text { fragment warsztatu pracy (np. kuchnię } \\
\text { w restauracji, gabinet weterynaryjny, } \\
\text { gabinet masażysty) za pomocą nazw } \\
\text { poszczególnych przedmiotów w języku } \\
\text { angielskim. }\end{array}$ \\
\hline
\end{tabular}




\begin{tabular}{|c|c|c|}
\hline $\begin{array}{l}\text { 5. Rozumie- } \\
\text { nie prostych } \\
\text { wypowiedzi } \\
\text { ustnych w języ- } \\
\text { ku angielskim } \\
\text { Realizacja } \\
\text { czynności } \\
\text { zawodowych } \\
\text { wjęzyku } \\
\text { angielskim }\end{array}$ & $\begin{array}{l}\text { Test językowy polegający na uzupeł- } \\
\text { nieniu pustych miejsc w zdaniach } \\
\text { o odpowiedni wyraz. Test ma spraw- } \\
\text { dzać znajomość słownictwa zawodo- } \\
\text { wego. Ponadto w treść opisywanych } \\
\text { sytuacji można włączyć zagadnienia } \\
\text { dotyczące kompetencji przekro- } \\
\text { jowych, takich jak praca w zespole, } \\
\text { adaptacja do zmiany, bezpieczeń- } \\
\text { stwo pracy. }\end{array}$ & $\begin{array}{l}\text { Osoba egzaminowana wysłuchuje } \\
\text { krótkiego (ok. 3-5 minut) nagrania } \\
\text { związanego z sytuacją zawodo- } \\
\text { wą. Może ono dotyczyć rozmowy } \\
\text { członków zespołu z liderem, rozmowy } \\
\text { z klientem w sprawach zawodowych } \\
\text { itp. Następnie osoba egzaminowana } \\
\text { ma za zadanie na podstawie testu wie- } \\
\text { lokrotnego wyboru wskazać odpowie- } \\
\text { dzi najtrafniej podsumowujące treść } \\
\text { wypowiedzi. }\end{array}$ \\
\hline $\begin{array}{l}\text { 6. Rozumie- } \\
\text { nie instrukcji } \\
\text { obsługi w języ- } \\
\text { ku angielskim } \\
\text { Realizacja } \\
\text { czynności } \\
\text { zawodowych } \\
\text { w języku } \\
\text { angielskim }\end{array}$ & $\begin{array}{l}\text { Zrozumienie instrukcji obsługi lub } \\
\text { regulaminów postępowania w języku } \\
\text { zawodowym to jedna z bardzo prak- } \\
\text { tycznych umiejętności. W zależności } \\
\text { od zawodu teksty techniczne mogą } \\
\text { dotyczyć zastosowania substancji } \\
\text { leczniczej lub urządzenia służącego } \\
\text { terapii (masażysta), obsługi maszyny, } \\
\text { dawkowania leku lub karmy (wetery- } \\
\text { narz) itp. }\end{array}$ & $\begin{array}{l}\text { Osoba egzaminowana ma za zadanie } \\
\text { przeczytać tekst instrukcji lub obsługi. } \\
\text { Następnie ma odpowiedzieć na serię } \\
\text { pytań po polsku sprawdzających, czy } \\
\text { poprawnie zrozumiała przeczytaną } \\
\text { instrukcję. }\end{array}$ \\
\hline 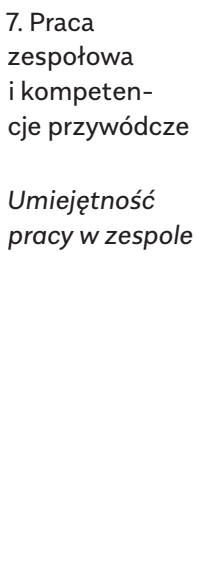 & $\begin{array}{l}\text { Osoba egzaminowana ma za zadanie } \\
\text { obserwować film, który przedsta- } \\
\text { wia spotkanie robocze zespołu } \\
\text { projektowego. W celu maksymalnego } \\
\text { przybliżenia kontekstu do sytuacji } \\
\text { zawodowej osoby egzaminowanej } \\
\text { film można nakręcić w różnych wer- } \\
\text { sjach - wersje będą różniły się: } \\
\text { a) tematyką rozwiązywane- } \\
\text { go problemu; } \\
\text { b) imionami bohaterów (aby utrudnić } \\
\text { uczniom uczenie się na pamięć). } \\
\text { Na obserwowanym filmie różne } \\
\text { postacie odgrywają różne role } \\
\text { w zespole. }\end{array}$ & 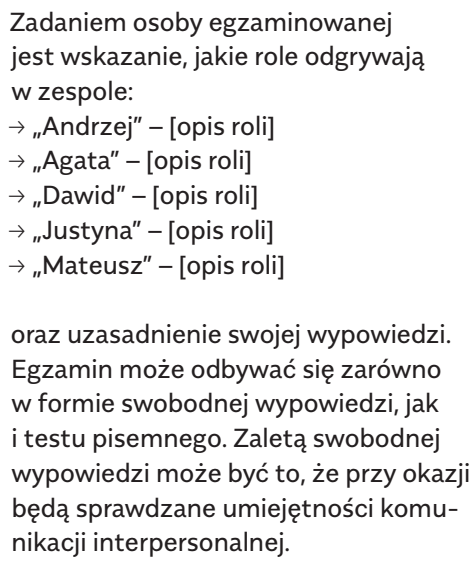 \\
\hline
\end{tabular}




\begin{tabular}{|c|c|c|}
\hline $\begin{array}{l}\text { 8. Kompeten- } \\
\text { cje medialne } \\
\text { Umiejętność } \\
\text { odpowiedzial- } \\
\text { nego odbioru } \\
\text { i interpretacji } \\
\text { komunikatów } \\
\text { medialnych }\end{array}$ & $\begin{array}{l}\text { Osoba egzaminowana ma za zadanie } \\
\text { obserwować film, który przedstawia } \\
\text { jedna po drugiej różnego rodzaju } \\
\text { wiadomości. }\end{array}$ & $\begin{array}{l}\text { Osoba egzaminowana powinna po } \\
\text { obejrzeniu filmu wskazać, które z prze- } \\
\text { kazanych wiadomości są: } \\
\rightarrow \text { faktami, } \\
\rightarrow \text { opiniami, } \\
\rightarrow \text { reklamą, } \\
\rightarrow \text { plotkami. } \\
\text { Ponadto wśród przekazywanych } \\
\text { informacji należy zidentyfikować styl } \\
\text { przekazu: } \\
\text { a) dramatyczny, } \\
\text { b) przesadzony. } \\
\text { Osoba egzaminowana ma wskazać, } \\
\text { czy dokonano manipulacji emocjami } \\
\text { odbiorcy w którymś z przekazów oraz } \\
\text { czy posługiwano się stereotypami. }\end{array}$ \\
\hline $\begin{array}{l}\text { 9. Zarządza- } \\
\text { nie konfliktem }\end{array}$ & $\begin{array}{l}\text { Osoba egzaminowana ma za zadanie } \\
\text { obserwować film, w którym przed- } \\
\text { stawiono konflikt w zespole. Lider } \\
\text { zespołu podejmuje próby rozwiąza- } \\
\text { nia konfliktu, rozmawiając z człon- } \\
\text { kami zespołu. Film można nakręcić } \\
\text { w różnych wersjach - wersje będą } \\
\text { różniły się: a) podłożem konfliktu; b) } \\
\text { imionami bohaterów (aby utrudnić } \\
\text { uczniom uczenie się na pamięć); c) } \\
\text { finałem sytuacji. W oglądanym filmie } \\
\text { różne postacie odgrywają różne role } \\
\text { w zespole. }\end{array}$ & $\begin{array}{l}\text { Osoba egzaminowana na podstawie } \\
\text { testu wielokrotnego wyboru ma za za- } \\
\text { danie wskazać odpowiedzi najtrafniej } \\
\text { podsumowujące dynamikę procesu } \\
\text { zarządzania konfliktem, zinterpreto- } \\
\text { wać zachowania członków zespołu, } \\
\text { ocenić trafność wybranych przez lidera } \\
\text { sposobów zarządzania konfliktem. }\end{array}$ \\
\hline $\begin{array}{l}\text { 10. Kreatyw- } \\
\text { ność w pra- } \\
\text { cy zawodowej } \\
\text { Kreatywność } \\
\text { i umiejętności } \\
\text { interpersonalne }\end{array}$ & $\begin{array}{l}\text { Celem tego zadania jest ocena } \\
\text { zdolności do tworzenia przez osobę } \\
\text { ocenianą kreatywnych rozwiązań. }\end{array}$ & $\begin{array}{l}\text { Miernikami kreatywności będą: } \\
\rightarrow \text { płynność - liczba rozwiązań, } \\
\rightarrow \text { giętkość - liczba kategorii rozwiązań, } \\
\rightarrow \text { oryginalność - statystyczna rzad- } \\
\text { kość występowania rozwiązań, } \\
\rightarrow \text { elaboracja - elegancja i precyzja } \\
\text { opisu rozwiązań. } \\
\text { Przy ocenie wyników kreatywności } \\
\text { niezbędne jest przeszkolenie egzami- } \\
\text { natorów oraz ocena zbiorowa (jury). } \\
\text { Kryterium „oryginalności" jest wysoce } \\
\text { subiektywne - zależy od wglądu } \\
\text { w szerszą pulę odpowiedzi udzielanych } \\
\text { przez osoby egzaminowane. Mierni- } \\
\text { kiem oryginalności jest statystyczna } \\
\text { rzadkość (1-5\% częstości występo- } \\
\text { wania wśród wszystkich udzielanych } \\
\text { odpowiedzi). }\end{array}$ \\
\hline
\end{tabular}




\begin{tabular}{|c|c|c|}
\hline $\begin{array}{l}\text { 11. Doskonale- } \\
\text { nie umiejętno- } \\
\text { ści zawodowych } \\
\text { Planowanie } \\
\text { własnego roz- } \\
\text { woju zawodo- } \\
\text { wego }\end{array}$ & $\begin{array}{l}\text { Osoba egzaminowana na podstawie } \\
\text { opisu fikcyjnej postaci ma zaplano- } \\
\text { wać jej rozwój zawodowy. Rozwią- } \\
\text { zanie zadania powinno polegać na } \\
\text { pisemnym sformułowaniu } 10 \text { reko- } \\
\text { mendacji dla postaci. Taka formuła } \\
\text { zadania umożliwia większą elastycz- } \\
\text { ność (w stosunku do wypowiedzi } \\
\text { we własnej sprawie). Jest to metoda } \\
\text { projekcyjna. }\end{array}$ & $\begin{array}{l}\text { Egzaminator ma przeanalizować treść } \\
\text { rekomendacji dla fikcyjnej postaci. }\end{array}$ \\
\hline $\begin{array}{l}\text { 12. Samoświa- } \\
\text { domość }\end{array}$ & $\begin{array}{l}\text { Osoba egzaminowana powinna doko- } \\
\text { nać oceny swoich silnych i słabych } \\
\text { stron. }\end{array}$ & $\begin{array}{l}\text { Ocena wykonania zadania odbywa } \\
\text { się na podstawie wnikliwości opisu } \\
\text { i uzasadnienia. Egzamin może zarówno } \\
\text { przyjąć formę swobodnej wypowiedzi, } \\
\text { jak i zostać ustrukturyzowany według } \\
\text { kwestionariusza egzaminacyjnego. }\end{array}$ \\
\hline $\begin{array}{l}\text { 13. Praca } \\
\text { zespołowa } \\
\text { Umiejętność } \\
\text { doboru człon- } \\
\text { ków zespołu }\end{array}$ & $\begin{array}{l}\text { Osoba egzaminowana ma do wyboru } \\
\text { charakterystyki ośmiu osób oraz opis } \\
\text { zadania. Powinna wskazać cztery, } \\
\text { które najlepiej nadają się do wykona- } \\
\text { nia danego zadania, oraz uzasadnić } \\
\text { swój wybór. Zadanie to może mieć } \\
\text { postać pisemną albo ustną. W przy- } \\
\text { padku odpowiedzi ustnej dodatkowo } \\
\text { sprawdzane byłyby umiejętności } \\
\text { komunikacji interpersonalnej. }\end{array}$ & $\begin{array}{l}\text { Ocena wykonania zadania odbywa } \\
\text { się na podstawie trafności wskazań } \\
\text { i doboru osób. Należy zadbać o to, aby } \\
\text { uniknąć zgadywania. Osoba egzamino- } \\
\text { wana powinna uzasadnić każdorazowo } \\
\text { swój wybór. }\end{array}$ \\
\hline $\begin{array}{l}\text { 14. Zdolność do } \\
\text { projektowania } \\
\text { (design } \\
\text { mindset) } \\
\text { Umiejętność } \\
\text { planowania } \\
\text { swojej pracy, } \\
\text { zarzqdzania } \\
\text { zasobami oraz } \\
\text { współpracy }\end{array}$ & $\begin{array}{l}\text { Sposób, w jaki zaprojektujemy } \\
\text { nasze otoczenie, ma wpływ na to, } \\
\text { jak postrzegamy świat oraz jak się } \\
\text { zachowujemy. Osoba egzaminowana } \\
\text { powinna w ramach tego zadania } \\
\text { zaprojektować proces, jaki wiąże } \\
\text { się z wykonywanym zawodem, np. } \\
\text { zaprojektować kuracje dla sportowca, } \\
\text { który doznał kontuzji (dla zawodu } \\
\text { masażysta). W ramach zadania } \\
\text { należy dokonać wizualizacji procesu, } \\
\text { opisać zasoby, ramy czasowe, ryzyka } \\
\text { oraz sposoby angażowania osób } \\
\text { trzecich (współpraca). }\end{array}$ & $\begin{array}{l}\text { Ocena powinna odbywać się według } \\
\text { następujących kryteriów: } \\
\text { 1. kompletności przekazanych infor- } \\
\text { macji (uwzględnienie wszystkich } \\
\text { kluczowych elementów), } \\
\text { 2. komunikatywności s, } \\
\text { 3. precyzji opisu, } \\
\text { 4. realności opisanego planu. }\end{array}$ \\
\hline $\begin{array}{l}\text { Stosowanie za- } \\
\text { sad komunikacji } \\
\text { interpersonal- } \\
\text { nej }\end{array}$ & $\begin{array}{l}\text { Stosowanie zasad komunikacji inter- } \\
\text { personalnej powinno opierać się na } \\
\text { ściśle opisanym katalogu zachowań } \\
\text { pożądanych i niepożąadanych. Osobie } \\
\text { egzaminowanej przedstawia się film, } \\
\text { na którym jego bohater w trakcie } \\
\text { prezentacji popełnia pewne błędy } \\
\text { w komunikacji interpersonalnej. } \\
\text { Zadaniem osoby egzaminowanej jest } \\
\text { ich identyfikacja. }\end{array}$ & $\begin{array}{l}\text { Ocena odbywa się na podstawie testu } \\
\text { pisemnego zawierającego listę poten- } \\
\text { cjalnych błędów w komunikacji. Osoba } \\
\text { egzaminowana ma za zadanie wskazać } \\
\text { błędy popełnione przez bohatera filmu. } \\
\text { Ponadto należy wskazać słabe i silne } \\
\text { strony bohatera filmu jako osoby } \\
\text { uczestniczącej w komunikacji interper- } \\
\text { sonalnej. }\end{array}$ \\
\hline
\end{tabular}




\begin{tabular}{|c|c|c|}
\hline $\begin{array}{l}\text { 16. Rozumie- } \\
\text { nie emocji + } \\
\text { kompetencje } \\
\text { międzykul- } \\
\text { turowe (+ ew. } \\
\text { język angielski) } \\
\text { Umiejętność } \\
\text { rozumienia } \\
\text { emocji innych, } \\
\text { empatia }\end{array}$ & $\begin{array}{l}\text { Celem zadania jest stwierdzenie, } \\
\text { w jakim stopniu osoba egzamino- } \\
\text { wana potrafi rozpoznawać i trafnie } \\
\text { określać emocje innych ludzi. Oprócz } \\
\text { samej identyfikacji emocji ważne jest } \\
\text { stwierdzenie, czy osoba egzamino- } \\
\text { wana umie właściwie reagować na te } \\
\text { emocje. }\end{array}$ & $\begin{array}{l}\text { Osoba egzaminowana analizuje sytu- } \\
\text { acje przedstawione za pomocą: } \\
\rightarrow \text { filmu, } \\
\rightarrow \text { komiksu, } \\
\rightarrow \text { opisu (narracji). } \\
\text { W opisanych sytuacjach występują } \\
\text { postacie wykonujące zadania związane } \\
\text { z egzaminowanymi kompetencjami } \\
\text { zawodowymi. W każdej z sytuacji } \\
\text { pojawia się interakcja, w której jeden } \\
\text { z bohaterów doświadcza pewnej } \\
\text { emocji (np. zawstydzenia, zakłopotania, } \\
\text { przestraszenia). Osoba egzaminowana } \\
\text { ma opisać (nazwać) tę emocję oraz: } \\
\text { a) opisać, czy osoba, której zachowanie } \\
\text { spowodowało tę emocję, zachowała się } \\
\text { poprawnie; } \\
\text { b) przedstawić, jeśli to potrzebne, inny } \\
\text { scenariusz (np. taki, w którym jedna } \\
\text { z osób nie została urażona). } \\
\text { Szczególnie warto podkreślić znacze- } \\
\text { nie kompetencji międzykulturowych } \\
\text { (kontakt z cudzoziemcem) oraz relacji } \\
\text { międzypokoleniowych (kontakt między } \\
\text { osobami młodą i starsza). }\end{array}$ \\
\hline
\end{tabular}

Źródło: opracowanie własne.

\section{Podsumowanie}

System edukacji opiera się na ponadczasowej zasadzie, którą Peter Drucker ujął tak: „What gets measured gets managed" ["Można zarządzać wszystkim, co można zmierzyć"] (Drucker 1954). Miał na myśli zjawisko orientacji zachowań ludzkich na kryteria oceniania. Innymi słowy, ludzie koncentrują swoją uwagę i energię na wykonywaniu działań, spełnianiu kryteriów, które podlegają ocenie. I na odwrót, jeśli dany obszar ludzkiej (potencjalnej) aktywności nie jest obiektem pomiaru i oceniania, staje się zaniedbywany. $Z$ taką sytuacją mamy do czynienia obecnie w systemach edukacji. $Z$ jednej strony, panuje powszechne przekonanie, że społeczeństwa i gospodarki potrzebują więcej innowacyjności, z drugiej zaś systemy edukacji nadal stawiają na te umiejętności i kompetencje, które zgodnie z wieloma prognozami nie będą potrzebne w przyszłości. Współczesny system egzaminów 
dość dobrze sparametryzował te obszary wiedzy i umiejętności, które w najbliższej przeszłości zostaną zastąpione przez sztuczną inteligencję. Aktywizacja i upodmiotowienie uczniów o ponadprzeciętnej kreatywności jest wielkim wyzwaniem dla systemów edukacji, które są jeszcze zakorzenione w XIX w. Tymczasem współczesny system edukacji raczej dyskryminuje uczniów kreatywnych. Winę ponosi m.in. istnienie podstawy programowej, która narzuca ramy dla sprawdzania wiedzy ucznia. Zmiany w systemach oświaty można by więc, zgodnie z obserwacją Petera Druckera, rozpocząć nie od zmian „wewnątrz" procesu edukacyjnego, lecz nieco przewrotnie, na jego końcu - tzn. przez zmianę sposobów, kryteriów oceniania i mierników. Mierniki te powinny dotyczyć szeroko rozumianej kreatywności uczniów. 